\title{
Buffer Solution Reduces Acidic Toothpaste Abrasivity Measured in Standardized Tests
}

\author{
Matthias Zehnder ${ }^{1 *}$, Luca Masoch ${ }^{1}$, Andrea Gubler ${ }^{1}$, Dirk Mohn ${ }^{1,2}$, Thomas Attin $^{1}$ and \\ Florian J. Wegehaupt ${ }^{1}$ \\ ${ }^{1}$ Conservative and Preventive Dentistry, University of Zurich, Zurich, Switzerland, ${ }^{2}$ Department of Chemistry and Applied \\ Biosciences, Institute for Chemical and Bioengineering, ETH Zurich, Zurich, Switzerland
}

OPEN ACCESS

Edited by:

Adriana Fernandes Da Silva,

Federal University of Pelotas, Brazil

Reviewed by:

Americo Bortolazzo Correr,

Campinas State University, Brazil

Carlos Enrique Cuevas-Suárez,

Autonomous University of the State of

Hidalgo, Mexico

Eliseu Aldrighi Munchow,

Federal University of Rio Grande do

Sul, Brazil

*Correspondence:

Matthias Zehnder

matthias.zehnder@zzm.uzh.ch

Specialty section:

This article was submitted to

Dental Materials,

a section of the journa

Frontiers in Dental Medicine

Received: 30 September 2020 Accepted: 04 November 2020

Published: 10 December 2020

Citation:

Zehnder M, Masoch L, Gubler A, Mohn D, Attin T and Wegehaupt FJ (2020) Buffer Solution Reduces Acidic

Toothpaste Abrasivity Measured in Standardized Tests.

Front. Dent. Med. 1:612298.

doi: 10.3389/fdmed.2020.612298
It has been speculated that the diluent used to test toothpaste abrasivity in standard tests may have an impact on their results, especially in the context of acidic toothpastes. This study tested whether an acidic toothpaste is indeed more abrasive than a neutral counterpart of otherwise identical composition, and whether this increased abrasivity is prevented by a buffered solution simulating saliva. Two experimental toothpastes of identical composition yet different $\mathrm{pH}$ (7.0 vs. 5.0) were prepared using standard ingredients. Subsequently, they were tested in standard absolute dentin abrasion and relative dentin abrasivity (RDA) experiments. To prepare slurries for these tests, deionized water as recommended by the International Organization for Standardization (ISO 11609:2017) was used, or a buffer solution containing bicarbonate and phosphate. The $\mathrm{pH}$ in these slurries was assessed and compared to the $\mathrm{pH}$ obtained in oral slurries of healthy individuals. Results showed that a significant (one-way ANOVA, $p<0.05$ ) increase in mean absolute dentin abrasion and RDA values by 35 and $14 \%$, respectively, was obtained when water was used as the diluent in conjunction with the acidic toothpaste as compared to the buffer solution. This was not the case with the neutral toothpaste. This result was explained by the finding that the buffer solution neutralized the $\mathrm{pH}$ in experimental slurries of the acidic toothpaste, while deionized water was unable to elevate the $\mathrm{pH}$ of the acidic toothpaste. That toothpaste was also neutralized in oral slurries. It was concluded that indeed the current ISO standard may result in a systematic overestimation of acidic toothpaste abrasivity.

Keywords: toothpaste, pH, abrasion, RDA, dentifrice, abrasivity, ISO standard

\section{INTRODUCTION}

Dentin abrasivity of toothpastes is an important information for consumers and is used by companies to advertise their products. According to the current ISO standard [11609:2017 (1)], there can be two main methods to test this feature in the laboratory: either a radiotracer-based method (2) or profilometry (3). Both methods can test relative dentin abrasion (i.e., abrasivity) by comparison to a reference abrasive material, and may thus be termed RDA tests [for relative dentin abrasivity, originally: radioactive-dentin abrasion (4)]. Unfortunately, results can differ rather tremendously between and even within these methods $(5,6)$, and a true correlation to clinics is elusive (7). Various reasons have been listed for these discrepancies, including the absence of a salivary pellicle in the laboratory setups (8), and the impact of the toothbrush bristles and how they are applied to/agitated on the dentin specimens (9-11). 
One additional possible confounding factor in laboratory tests on dentifrice abrasivity is the diluent that is used. Harte and Manly found that when they used standard abrasives, glycerin, i.e., common humectant in most toothpastes, greatly reduced their abrasive effect, while whole saliva and $2 \%$ aqueous carboxymethyl cellulose did not. This may be why in the current ISO standard (1), $25 \mathrm{~g}$ of the toothpaste to be tested is diluted in $40 \mathrm{~mL}$ of deionized or distilled water, as was originally recommended by the Laboratory Committee of the American Dental Association (2). The current RDA test at the University of Zurich, however, uses a buffer solution containing bicarbonate and phosphate to simulate the main buffers present in saliva $(12,13)$ to dilute the toothpastes. This was based on the argument that acidic toothpastes may otherwise yield erroneously high RDA values in the test (14). Indeed, when non-buffered $0.5 \%$ sodium carboxymethyl cellulose was used as a diluent, an acidic $\mathrm{pH}$ of a toothpaste appeared to have an impact on its in vitro dentin abrasivity because of a purported erosive/abrasive effect (15). Moreover, an acidic toothpaste caused more unpleasant clinical effects such as sensitivity compared to neutral or alkaline counterparts (16). These results, however, did not establish a cause-effect relationship, as the commercial toothpastes under investigation did not only differ in their $\mathrm{pH}$, but also in their abrasive particle content. Hence, it is still not clear whether the $\mathrm{pH}$ itself can affect toothpaste abrasivity, and how a buffered system with a $\mathrm{pH}$ and buffer capacity simulating that of saliva might affect results in different standard laboratory setups. This was tested in the current study using experimental toothpastes of identical content but different $\mathrm{pH}$. Absolute dentin abrasion was determined using profilometry, relative dentin abrasivity was evaluated using a radioactive tracer method (17). To compare the $\mathrm{pH}$ values obtained in the experimental toothpaste/diluent slurries with the in situ environment, the $\mathrm{pH}$ values in oral whole saliva/tooth paste slurries were determined in healthy human volunteers after 1 min of tooth brushing.

The hypothesis of this study was that in an acidic environment, toothpaste abrasivity is increased. This environment, however, should be influenced by the solution the toothpaste is diluted in. Buffered solutions such as saliva might thus reduce the abrasivity of acidic toothpastes by neutralizing their $\mathrm{pH}$.

\section{MATERIALS AND METHODS}

\section{Diluents}

Two diluents were used in this study to obtain the toothpaste slurries: (1) deionized water (MicroPure Model 08.1202, TKA, Niederlebert, Germany) as recommended in the ISO standard (1); and (2) a buffer solution simulating saliva as described (14). The latter was always prepared freshly on the day of the individual experiments (Table 1), and then used in the subsequent experiments as described below. The pure buffer solution had a $\mathrm{pH}$ of 7.9 .

\section{Experimental Toothpastes}

Two toothpastes were specifically prepared for this study: an acidic paste $(\mathrm{pH}$ ) and a $\mathrm{pH}$-neutral counterpart $(\mathrm{pH})$.
TABLE 1 | Contents (wt/vol) of the buffer solution used as a diluent in this study.

\begin{tabular}{llc}
\hline Chemical & Formula & mg/L \\
\hline Potassium chloride & $\mathrm{KCl}$ & 1,080 \\
Sodium chloride & $\mathrm{NaCl}$ & 765 \\
Magnesium chloride & $\mathrm{MgCl}_{2} \times 6 \mathrm{H}_{2} \mathrm{O}$ & 45 \\
Calcium chloride & $\mathrm{CaCl}_{2} \times 2 \mathrm{H}_{2} \mathrm{O}$ & 90 \\
Potassium thiocyanate & $\mathrm{KSCN}$ & 90 \\
Monopotassium phosphate & $\mathrm{KH}_{2} \mathrm{PO}_{4}$ & 315 \\
Boric acid & $\mathrm{H}_{3} \mathrm{BO}_{3}$ & 45 \\
Sodium bicarbonate & $\mathrm{NaHCO}_{3}$ & 1,889 \\
\hline
\end{tabular}

Pastes were prepared in $100 \mathrm{~g}$ batches using the ingredients listed in Table 2. These were weighed in a precision balance (PM 300, Mettler Toledo, Greifensee, Switzerland). Pastes were mixed in a custom-made device consisting of a professional stirrer (Hei-Torque Precision 100, Heidolph Instruments GmbH \& CO. KG, Schwabach, Germany) placed on a heating plate (RCT basic, IKA-Werke, Stauffen, Germany) and connected to a vacuum pump (VACUUBRAND, Wertheim, Germany). Ingredients were added in sequence under specific conditions (Table 2) to ensure homogeneity of the final paste. Especially the sodium carboxymethyl cellulose needed to be added in small amounts over a period of $20 \mathrm{~min}$ to avoid clumping. This and the subsequent steps (Table 2) were performed using a vacuum pump to reduce entrapped air in the mixture. Stirring speed was also adjusted in each step and reduced in the later steps to avoid foaming (Table 2). In a final step, $1 \mathrm{~mol} / \mathrm{L} \mathrm{HCl}$ (Honeywell, Seelze, Germany) or $1 \mathrm{~mol} / \mathrm{L} \mathrm{NaOH}$ (AppliChem, Darmstadt, Germany) was added in small amounts until the resulting paste had the desired $\mathrm{pH}$ of 5.0 or 7.0 (the unadjusted paste had a $\mathrm{pH}$ of 6.1).

\section{Absolute Dentin Abrasion Test}

Dentin specimens were obtained as described (18). In brief, specimens were prepared post mortem from bovine teeth obtained from animals that were held and slaughtered for food production according to the Swiss Animal Welfare Act (19). Hence, this study was not considered an animal study according to local legislature. The lower incisors were extracted, mechanically cleaned, and decoronated under water cooling using a low-speed saw (Isomet Buehler Model Nr.11-1280-250, Buehler, Lake Bluff, IL, USA) equipped with a diamond wheel (MOD10, Struers, Birmensdorf, Switzerland). Only the roots were used. Four dentin cylinders per root were obtained from the coronal $2 / 3$ of the root at least $1 \mathrm{~mm}$ away from the dentinenamel junction using a trephine bur with $3 \mathrm{~mm}$ inner diameter (Proxxon, Brütsch/Rüegger Werkzeuge, Urdorf, Switzerland) applied right-angled to the long axis of the root. A total of 20 bovine lower incisor roots was used for these experiments $(N=$ 20). The four cylinders per root were later randomly distributed to the four groups to avoid any clustering effect. Using cylindrical silicone molds, dentin cylinders were embedded in Paladur (Heraeus Kulzer, Hanau, Germany) and standardized to $4 \mathrm{~mm}$ length using a carbide milling cutter (Proxxon, Brütsch/Rüegger 
TABLE 2 | Composition, mixing steps and stirring parameters of experimental toothpastes.

\begin{tabular}{|c|c|c|c|c|c|c|}
\hline Step & Ingredients & Amount [g] & Time [min] & Speed [rpm] & Temperature $\left[{ }^{\circ} \mathbf{C}\right]$ & Vacuum [mbar] \\
\hline \multirow[t]{3}{*}{1} & Deionized water & 48 & & & & \\
\hline & Sorbitol (70\% in water) & 23.2 & & & & \\
\hline & Polyethylene glycol (400) & 3.5 & 5 & 100 & $40-50$ & - \\
\hline \multirow[t]{2}{*}{2} & Saccharine sodium & 0.1 & & & & \\
\hline & Sodium benzoate & 0.2 & 5 & 250 & $35-45$ & - \\
\hline 3 & Sodium carboxymethyl cellulose & 0.5 & 20 & 450 & $35-45$ & - \\
\hline \multirow[t]{2}{*}{4} & Sident 9 & 9 & & & & \\
\hline & Sident 22s & 9 & 15 & 100 & $35-45$ & - \\
\hline 5 & Sodium dodecyl sulfate & 1.5 & 5 & 50 & $35-45$ & $500-600$ \\
\hline 6 & $\mathrm{pH}_{\text {adjustment }}^{\star}$ & 5 & & & & \\
\hline
\end{tabular}

*1 mol/ $\mathrm{L} \mathrm{HCl}$ or $\mathrm{NaOH}$ was added until target $\mathrm{pH}$ was reached and then deionized water was added to $5 \mathrm{~g}$ total weight.

Werkzeuge AG). These acrylic resin/dentin cylinders were then polished down to 4000 Grit in a respective device (Tegramin 30, Struers $\mathrm{GmbH}$, Willich, Germany) operated at $150 \mathrm{rpm}$ and $5 \mathrm{~N}$. On the dentin surface, two parallel notches were prepared in the Paladur using a scalpel. Using these indentations as reference lines, five parallel profilometry measurements were performed in a precision surface testing station (MarSurd GD25, Mahr GmbH, Göttingen, Germany) at a distance of $250 \mu \mathrm{m}$ between them. To ensure an exact repositioning of the samples during the pre- and post-brushing recording of the surface profiles, the profilometer and the acrylic resin/dentin cylinders were equipped with a jig.

For the toothpaste abrasivity test, slurries were prepared from $20 \mathrm{~g}$ paste and $40 \mathrm{~g}$ deionized water or buffer solution. Subsequently, $0.1 \mathrm{~g}$ Silicone Antifoam was added (Art-85390, Sigma Aldrich GmbH, Steinheim, Germany). The mixture was dispersed for $5 \mathrm{~min}$ prior to the absolute dentin abrasion test (Ultra Turrax T25, IKA-Werke). Dentin specimens were then subjected to abrasivity testing in an automated brushing machine (20). They were fixed in holders in individual vials and covered with $5 \mathrm{~mL}$ of test or control slurries. The machine was adjusted to a constant brushing frequency of 60 cycles (120 strokes) per minute and a constant brushing force of $2.5 \mathrm{~N}$ for $25 \mathrm{~min}$ (21). A medium bristle stiffness toothbrush was used (ParoM43, Esro AG, Thalwil, Zürich, Switzerland). This set-up ensured that the specimens were covered with the slurry during the whole brushing procedure. After this procedure, the specimens were rinsed for $10 \mathrm{~s}$ in tap water and re-evaluated in the surface testing station as described above. Specimens were kept in tap water throughout these experiments (22). Absolute abrasion tests were performed on 20 specimens per group $(N=20)$.

\section{Relative Dentin Abrasivity (RDA) Test}

Eight bovine tooth roots per toothpaste to be tested were irradiated alio loco. Due to the irradiation, the phosphor of the apatite was changed to radioactive ${ }^{32} \mathrm{P}$.

The roots were embedded in Paladur (Heraeus Kulzer) and later brushed in an automatized 8-slot brushing machine (14) during $25 \mathrm{~min}$ as described above. The brushing media were either a slurry prepared from the toothpastes or a slurry prepared from a standard abrasive. For the slurry preparation, $25 \mathrm{~g}$ of toothpaste was mixed with $40 \mathrm{~g}$ of the diluent, i.e., the buffer solution (Table 1) or deionized water and $50 \mu$ l silicon Antifoam agent during $5 \mathrm{~min}$ (14). The standard slurry was prepared by mixing $10 \mathrm{~g}$ ISO Sident and $50 \mathrm{~g}$ of buffer solution (Table 1). The brushing runs were performed in a so-called "sandwich" technique. Therefore, first a run with the standard abrasive slurry, then a run with the test-toothpaste slurry and finally again a run with the standard abrasive slurry was performed.

After each run, $2 \mathrm{~g}$ of the used slurries were collected and the ${ }^{32} \mathrm{P}$-irradiation in "decays per minute" ( $\left.\mathrm{dpm}\right)$ were measured using a Liquid Scintillation Counter (Packard Instrument Company, Meriden, CT, USA). The ${ }^{32} \mathrm{P}$-amount in the slurry after brushing is a measure for the dental hard tissue abrasion of the tested products. The values for the standard abrasive slurry runs of the "sandwich" technique were averaged and the values of the test-toothpastes were expressed relative to this value.

\section{pH Measurements}

All $\mathrm{pH}$ measurements in this study were performed using a calibrated microelectrode (Metrohm 780, Herisau, Switzerland) in triplicate measurements. Experimental slurries as used in the in vitro experiments were measured by directly placing this electrode into the respective slurry. To assess the $\mathrm{pH}$ of the acidic toothpaste under investigation under real-live conditions, seven healthy volunteers (three females and four males, aged 30 to 51) from the laboratory personnel brushed their teeth for $1 \mathrm{~min}$ with this paste and then spit the resulting whole saliva/toothpaste slurry into individual polypropylene beakers (Semadeni, Ostermundigen, Switzerland) to assess the $\mathrm{pH}$ as described. They each used $1 \mathrm{~g}$ of each toothpaste under investigation on a ParoM43 (Esro AG) toothbrush. These experiments were done using the neutral toothpaste first and the acidic counterpart at least $1 \mathrm{~h}$ later. An individual ethics approval was not obtained for this experiment using standard materials and anonymized samples, as this was not necessary under local law (23).

\section{Data Presentation and Analysis}

Results from the absolute dentin abrasion test are presented as $\mu \mathrm{m}$ in vertical dentin loss. The relative dentin abrasivity (RDA) of the toothpastes under investigation were expressed in full numbers relative to the standard abrasive that was used (RDA 
TABLE 3 | Ordered difference (in $\mu \mathrm{m}$ ) report of the experiment on absolute dentin abrasion according to the different experimental toothpaste-diluent combinations

\begin{tabular}{|c|c|c|c|}
\hline Level & Level & Difference $(\mu \mathrm{m})$ & $p$-Value \\
\hline $\begin{array}{l}\text { Acidic paste in water } \\
(\mathrm{pH} 5.1)\end{array}$ & $\begin{array}{l}\text { Acidic paste in buffer } \\
(\mathrm{pH} 7.2)\end{array}$ & 1.9 & 0.0005 \\
\hline $\begin{array}{l}\text { Acidic paste in water } \\
(\mathrm{pH} 5.1)\end{array}$ & $\begin{array}{l}\text { Neutral paste in } \\
\text { water } \\
(\mathrm{pH} 7.1)\end{array}$ & 1.6 & 0.0049 \\
\hline $\begin{array}{l}\text { Acidic paste in water } \\
(\mathrm{pH} 5.1)\end{array}$ & $\begin{array}{l}\text { Neutral paste in } \\
\text { buffer } \\
\text { (pH 7.5) }\end{array}$ & 1.4 & 0.0139 \\
\hline $\begin{array}{l}\text { Neutral paste in } \\
\text { buffer } \\
\text { (pH 7.5) }\end{array}$ & $\begin{array}{l}\text { Acidic paste in buffer } \\
(\mathrm{pH} 7.2)\end{array}$ & 0.5 & 0.7180 \\
\hline $\begin{array}{l}\text { Neutral paste in } \\
\text { water } \\
(\mathrm{pH} 7.1)\end{array}$ & $\begin{array}{l}\text { Acidic paste in buffer } \\
(\mathrm{pH} 7.2)\end{array}$ & 0.3 & 0.9147 \\
\hline $\begin{array}{l}\text { Neutral paste in } \\
\text { buffer } \\
\text { (pH 7.5) }\end{array}$ & $\begin{array}{l}\text { Neutral paste water } \\
(\mathrm{pH} 7.1)\end{array}$ & 0.2 & 0.9798 \\
\hline
\end{tabular}

85). The $\mathrm{pH}$ values in the different experimental set-ups are listed as medians and ranges. Data pertaining to the absolute dentin abrasion and RDA tests were normally distributed (Shapiro-Wilk test) and therefore compared between groups using parametric statistics: one-way ANOVA and Tukey's HSD test. The alpha-type error was set to $5 \%(p<0.05)$.

\section{RESULTS}

Absolute vertical dentin abrasion under the conditions of this study was the highest with the acidic toothpaste when it was mixed with deionized water: $7.4 \pm 1.5 \mu \mathrm{m} / 25 \mathrm{~min}$ of brushing ( $p<0.05$ compared to all other groups, Table 3 ). Using the buffer solution described in Table 1 with the same experimental toothpaste, vertical dentin abrasion dropped to 5.5 $\pm 1.5 \mu \mathrm{m}$. With the $\mathrm{pH}$-neutral toothpaste, the corresponding mean abrasion values were $5.8 \pm 1.2$ and $6.0 \pm 1.4 \mu \mathrm{m}$ with water or the buffer solution as the diluent, respectively $(p>0.5$ between these groups, Table 3 ). Hence, under these conditions, using mere distilled water rather than a buffer solution, that neutralized the $\mathrm{pH}$ in the experimental slurry (Table 4), increased the mean absolute value by $35 \%$ with the acidic toothpaste, while the buffer solution itself did not impact abrasion values.

In the relative dentin abrasivity test, results were comparable and statistical differences were similar to the absolute abrasion test (Figure 1). With an RDA of $64 \pm 3$, the acidic toothpaste in conjunction with water as the diluent was the most abrasive combination ( $p<0.05$ compared to all other groups). Changing the diluent from water to the buffer solution decreased the RDA to $56 \pm 3$. This corresponds to an increase in the mean RDA value by $14 \%$ when slurries were prepared with deionized water. Again, the buffer solution itself did not affect RDA values compared to water (Figure 1, values obtained with neutral toothpaste).
TABLE 4 | pH values of experimental toothpastes ${ }^{a}$ and slurries as compared to the oral environment.

\begin{tabular}{|c|c|c|c|}
\hline Experiment & Paste $^{a}$ & Slurry & $\mathrm{pH}$ \\
\hline \multirow[t]{2}{*}{ Native $\mathrm{pH}$} & Acidic & - & 5.0 \\
\hline & Neutral & - & 7.0 \\
\hline \multirow[t]{4}{*}{$\begin{array}{l}\text { Absolute dentin } \\
\text { abrasion }\end{array}$} & Acidic & $\begin{array}{l}\text { Deionized water (66.6 wt\%) } \\
\text { Silicone antifoam (0.2 wt\%) }\end{array}$ & 5.1 \\
\hline & & $\begin{array}{l}\text { Buffer solution }{ }^{\mathrm{a}}(66.6 \text { wt\%) } \\
\text { Silicone antifoam (0.2 wt\%) }\end{array}$ & 7.2 \\
\hline & Neutral & $\begin{array}{l}\text { Deionized water (66.6 wt\%) } \\
\text { Silicone antifoam (0.2 wt\%) }\end{array}$ & 7.1 \\
\hline & & $\begin{array}{l}\text { Buffer solution (66.6 wt\%) } \\
\text { Silicone antifoam (0.2 wt\%) }\end{array}$ & 7.5 \\
\hline \multirow[t]{4}{*}{$\begin{array}{l}\text { Relative dentin } \\
\text { abrasivity (RDA) }\end{array}$} & Acidic & $\begin{array}{l}\text { Deionized water (61.5 wt\%) } \\
\text { Silicone antifoam (0.1 wt\%) }\end{array}$ & 5.1 \\
\hline & & $\begin{array}{l}\text { Buffer solution (61.5 wt\%) } \\
\text { Silicone antifoam (0.1 wt\%) }\end{array}$ & 7.0 \\
\hline & Neutral & $\begin{array}{l}\text { Deionized water (61.5 wt\%) } \\
\text { Silicone antifoam (0.1 wt\%) }\end{array}$ & 6.8 \\
\hline & & $\begin{array}{l}\text { Buffer solution (61.5 wt\%) } \\
\text { Silicone antifoam (0.1 wt\%) }\end{array}$ & 7.3 \\
\hline \multirow[t]{2}{*}{ In situ pH } & Acidic & Human whole saliva & $7.4(6.5-7.6)^{b}$ \\
\hline & Neutral & Human whole saliva & $7.4(6.9-7.6)^{b}$ \\
\hline
\end{tabular}

${ }^{a}$ As described in Table 2; ${ }^{b}$ median (range).

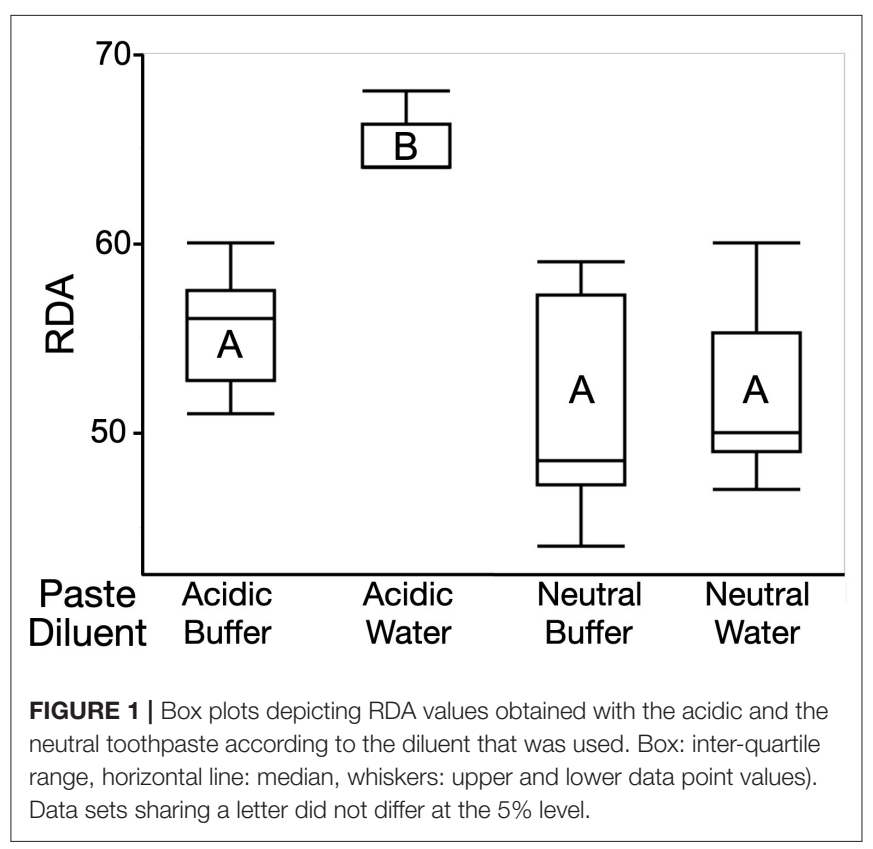

The buffer solution used in this study (Table 1) neutralized acidic toothpaste $\mathrm{pH}$ values in the slurries used for the standard tests (Table 4). This was similar to the $\mathrm{pH}$ neutralization observed in oral slurries after $1 \mathrm{~min}$ of toothbrushing with the acidic toothpaste (Table 4), when a median $\mathrm{pH}$ value of 7.4 was observed. In contrast, experimental toothpaste slurries remained unaffected when distilled water was used as the diluent. 


\section{DISCUSSION}

This study showed that using deionized water as a diluent for in vitro toothpaste assessment can create a non-realistic $\mathrm{pH}$ environment. With acidic toothpastes, this can lead to systematic over-estimation of abrasivity.

The current study was controlled in multiple aspects: toothpastes that merely differed in $\mathrm{pH}$ were prepared specifically for this investigation and therefore, the impact of $\mathrm{pH}$ in the in vitro tests under investigation, and also possible effect of the buffer solution used to make the experimental slurries could be singled out. The results unequivocally showed that both toothpastes abraded dentin similarly when their $\mathrm{pH}$ was adjusted, and that the acidic toothpaste was more aggressive on dentin when water was used as the diluent as recommended by the current ISO standard (1).

A limitation of the present study was the use of bovine dentin samples instead of human dentin as recommended by the International Organization for Standardization. However, different studies $(18,24)$ investigating the usability of bovine dentin to substitute human dentin in abrasivity tests have shown that the easily available bovine substrate does not introduce systematic error. Moreover, as long as the obtained results are compared within a specific study and with results obtained for standard abrasives within the same study, a replacement of human by bovine dentin appears to be acceptable. A further limitation of this study is that the absolute dentin abrasion and the RDA test did not employ the exact same types of dentin specimens. This was done deliberately to assess the hypothesis of this study under different conditions, which are not strictly defined by the norm. It must be conceded, however, that the toothpaste to diluent ratio used in the absolute dentin abrasion test described here $(20 \mathrm{~g}$ to $40 \mathrm{~mL}$ ) different slightly from the recommended ration ( $25 \mathrm{~g}$ in $40 \mathrm{~mL}$ ), which was used in the RDA test. This was done because the above ratio is used routinely in our laboratory, and explains the slight differences in $\mathrm{pH}$ values of the slurries (Table 4). This minor difference in $\mathrm{pH}$, however, did not have any influence on the results reported here.

The experimental toothpastes were prepared following the typical composition of toothpastes. Abrasives were suspended in an aqueous humectant phase by means of a hydrocolloid. In this matrix, surfactants, active ingredients, flavor compounds, sweeteners, colorings, preservatives and other excipients are embedded (25). To reduce the complexity of the composition, certain compounds such as fluorides and flavoring additives were not included. As the present study aimed to evaluate the abrasivity as function of the $\mathrm{pH}$ of the toothpastes and the used diluent, this reduction seems to be justifiable.

Human saliva contains three major systems contributing to its buffer capacity, i.e., the bicarbonate, the phosphate, and the protein system (13). Human whole saliva has a buffer zone spanning from $\mathrm{pH} 3.4$ to 8 compassing the buffer ranges of proteins ( $\mathrm{pH} 3.4$ to 5), bicarbonate $(\mathrm{pH} 5.1$ to 7.1 ) and monosodium phosphate ( $\mathrm{pH} 6.1$ to 8.1 ) (26). It should be noted that the buffer solution used here (Table 1), which has been used routinely on our laboratory (14), does not contain proteins.
The $\mathrm{pH}$ values of the experimental toothpastes $(\mathrm{pH} 5.0$ and 7.0) are comparable to those of commercially available toothpastes (5.6-9.2) (27). Typical examples of acidic toothpastes are Elmex Caries Protection ( $\mathrm{pH}$ 5.9) and Elmex Protection Erosion (pH 5.6) (both GABA, Therwil, Switzerland). For these toothpastes it might be assumed that the acidic $\mathrm{pH}$ is due to the content of amine fluoride (Olaflur). As amine fluoride is acidic one might assume that it has an acidic capacity that is higher than that of the acidic toothpaste under investigation, which merely contained relatively minute amounts of $\mathrm{HCl}$. Indeed, in pilot experiments, we found that the buffer used in this study (Table 1) could not elevate the $\mathrm{pH}$ of commercially available acidic toothpaste to the same extent as it did with the experimental acidic toothpaste described here (Table 2). Different buffer systems including saliva substitutes containing mucin have been used to replace human saliva in erosion/abrasion models (28). Future studies should thus compare the buffer capacity of different saliva substitutes with that of natural saliva with regards to its influence on the performance of commercially available acidic toothpaste abrasivity.

In summary, the current study showed that in the context of acidic toothpastes, the current norm recommending deionized water as the diluent in toothpaste abrasivity tests (1) may not yield clinically reliable results, as there appears to be an erosive component that is not corrected for. Future studies should assess different buffer solutions for their ability to create realistic $\mathrm{pH}$ environments in conjunction with commercially available acidic toothpastes in relative dentin abrasivity (RDA) tests.

\section{DATA AVAILABILITY STATEMENT}

The raw data supporting the conclusions of this article will be made available by the authors, without undue reservation.

\section{ETHICS STATEMENT}

Ethical review and approval was not required for the study on human participants in accordance with the local legislation and institutional requirements. The patients/participants provided their written informed consent to participate in this study.

\section{AUTHOR CONTRIBUTIONS}

MZ, AG, DM, TA, and FW: study design. LM and AG: data collection. MZ: data analysis, drafting manuscript, and takes responsibility for the integrity of the data analysis. AG, DM, TA, and FW: revising manuscript content. MZ, LM, AG, DM, TA, and FW: approving final version of manuscript. All authors contributed to the article and approved the submitted version.

\section{FUNDING}

This research was supported by institutional funds. The fee for open access publication was partly covered by University of Zurich. 


\section{REFERENCES}

1. International Association for Standardization (ISO) Geneva, Switzerland (2017). Available online at: https://www.iso.org/standard/70956.html

2. Hefferren JJ. A laboratory method for assessment of dentrifrice abrasivity. $J$ Dent Res. (1976) 55:563-73. doi: 10.1177/00220345760550040301

3. Noordmans J, Pluim LJ, Hummel J, Arends J, Busscher HJ. A new profilometric method for determination of enamel and dentinal abrasion in vivo using computer comparisons: a pilot study. Quintessence Int. (1991) 22:653-7.

4. Grabenstetter RJ, Broge RW, JJackson FL, Radike AW. The measurement of the abrasion of human teeth by dentifrice abrasives: a test utilizing radioactive teeth. J Dent Res. (1958) 37:1060-8. doi: 10.1177/00220345580370060601

5. Barbakow F, Lutz F, Imfeld T. A critical comparison of dentifrice abrasion scores on dentine recorded by gravimetric and radiotracer methods. J Dent. (1992) 20:283-6. doi: 10.1016/0300-5712(92)90048-H

6. Addy M, Hughes J, Pickles MJ, Joiner A, Huntington E. Development of a method in situ to study toothpaste abrasion of dentine. Comparison of 2 products. J Clin Periodontol. (2002) 29:896-900. doi: 10.1034/j.1600-051X.2002.291004.x

7. Dörfer CE. Abrasivity of dentifrices from a clinical perspective. J Clin Dent. (2010) 21:S4.

8. Joiner A, Schwarz A, Philpotts CJ, Cox TF, Huber K, Hannig M. The protective nature of pellicle towards toothpaste abrasion on enamel and dentine. J Dent. (2008) 36:360-8. doi: 10.1016/j.jdent.2008.01.010

9. Harte DB, Manly RS. Four variables affecting magnitude of dentrifice abrasiveness. J Dent Res. (1976) 55:3227. doi: 10.1177/00220345760550030601

10. Wiegand A, Kuhn M, Sener B, Roos M, Attin T. Abrasion of eroded dentin caused by toothpaste slurries of different abrasivity and toothbrushes of different filament diameter. J Dent. (2009) 37:480-4. doi: 10.1016/j.jdent.2009.03.005

11. Dörfer CE, Hefferren JJ, Gonzàlez-Cabezas C, Imfeld T, Addy M. Methods to determine dentifrice abrasiveness. J Clin Dent. (2010) 21:S1-6.

12. Leung SW. A demonstration of the importance of bicarbonate as a salivary buffer. J Dent Res. (1951) 30:403-14. doi: 10.1177/002203455103000 31601

13. Bardow A, Moe D, Nyvad B, Nauntofte B. The buffer capacity and buffer systems of human whole saliva measured without loss of CO2. Arch Oral Biol. (2000) 45:1-12. doi: 10.1016/S0003-9969(99)00119-3

14. Imfeld $\mathrm{T}$. Standard operation procedures for the relative dentin abrasion (RDA) method used at the University of Zurich. J Clin Dent. (2010) 21: S11-12.

15. Svinnseth PN, Gjerdet NR, Lie T. Abrasivity of toothpastes. An in vitro study of toothpastes marketed in Norway. Acta Odontol Scand. (1987) 45:195202. doi: $10.3109 / 00016358709098859$
16. Bruno M, Taddeo F, Medeiros IS et al. Relationship between toothpastes properties and patient-reported discomfort: crossover study. Clin Oral Investig. (2016) 20:485-94. doi: 10.1007/s00784-015-1539-8

17. Barbakow F, Imfeld T, Lutz F, Stookey G, Schemehorn B. Dentin abrasion (RDA), enamel abrasion (REA) and polishing scores of dentifrices sold in Switzerland. Schweiz Monatsschr Zahnmed. (1989) 99:408-13.

18. Wegehaupt FJ, Widmer R, Attin T. Is bovine dentine an appropriate substitute in abrasion studies. Clin Oral Investig. (2010) 14:201-5. doi: 10.1007/s00784-009-0283-3

19. Swiss Federal Council. Swiss Animal Welfare Act. Available online at: https:// www.blv.admin.ch/blv/en/home/tiere/tierschutz.html

20. Imfeld T. Comparison of the mechanical effects of a toothbrush and standard abrasive on human and bovine dentine in vitro. J Clin Dent. (2001) 12:92-6.

21. Hamza B, Tanner M, Attin T, Wegehaupt FJ. Dentin abrasivity and cleaning efficacy of novel/alternative toothpastes. Oral Health Prev Dent. (2020) 18:713-8. doi: 10.3290/j.ohpd.a45074

22. Attin T, Becker K, Roos M, Attin R, Paqué F. Impact of storage conditions on profilometry of eroded dental hard tissue. Clin Oral Investig. (2009) 13:473-8. doi: 10.1007/s00784-009-0253-9

23. Council SF. Federal Act on Research Involving Human Beings.

24. Wegehaupt F, Gries D, Wiegand A, Attin T. Is bovine dentine an appropriate substitute for human dentine in erosion/abrasion tests. J Oral Rehabil. (2008) 35:390-4. doi: 10.1111/j.1365-2842.2007.01843.x

25. Lippert F. An introduction to toothpaste - its purpose, history and ingredients. Monogr Oral Sci. (2013) 23:1-14. doi: 10.1159/000350456

26. Lamanda A, Cheaib Z, Turgut MD, Lussi A. Protein buffering in model systems and in whole human saliva. PLoS ONE. (2007) 2:e263. doi: 10.1371/journal.pone.0000263

27. Aykut-Yetkiner A, Attin T, Wiegand A. Prevention of dentine erosion by brushing with anti-erosive toothpastes. J Dent. (2014) 42:856-61. doi: 10.1016/j.jdent.2014.03.011

28. Hara AT, González-Cabezas C, Creeth J, Zero DT. The effect of human saliva substitutes in an erosion-abrasion cycling model. Eur J Oral Sci. (2008) 116:552-6. doi: 10.1111/j.1600-0722.2008.00575.x.

Conflict of Interest: The authors declare that the research was conducted in the absence of any commercial or financial relationships that could be construed as a potential conflict of interest.

Copyright (C) 2020 Zehnder, Masoch, Gubler, Mohn, Attin and Wegehaupt. This is an open-access article distributed under the terms of the Creative Commons Attribution License (CC BY). The use, distribution or reproduction in other forums is permitted, provided the original author(s) and the copyright owner(s) are credited and that the original publication in this journal is cited, in accordance with accepted academic practice. No use, distribution or reproduction is permitted which does not comply with these terms. 